\title{
ANALISIS PERBEDAAN PENGARUH PREMI, KLAIM, DAN INVESTASI TERHADAP PERTUMBUHAN LABA PADA PERUSAHAAN ASURANSI SYARIAH DENGAN ASURANSI KONVENSIONALPERIODE 2011-2013
}

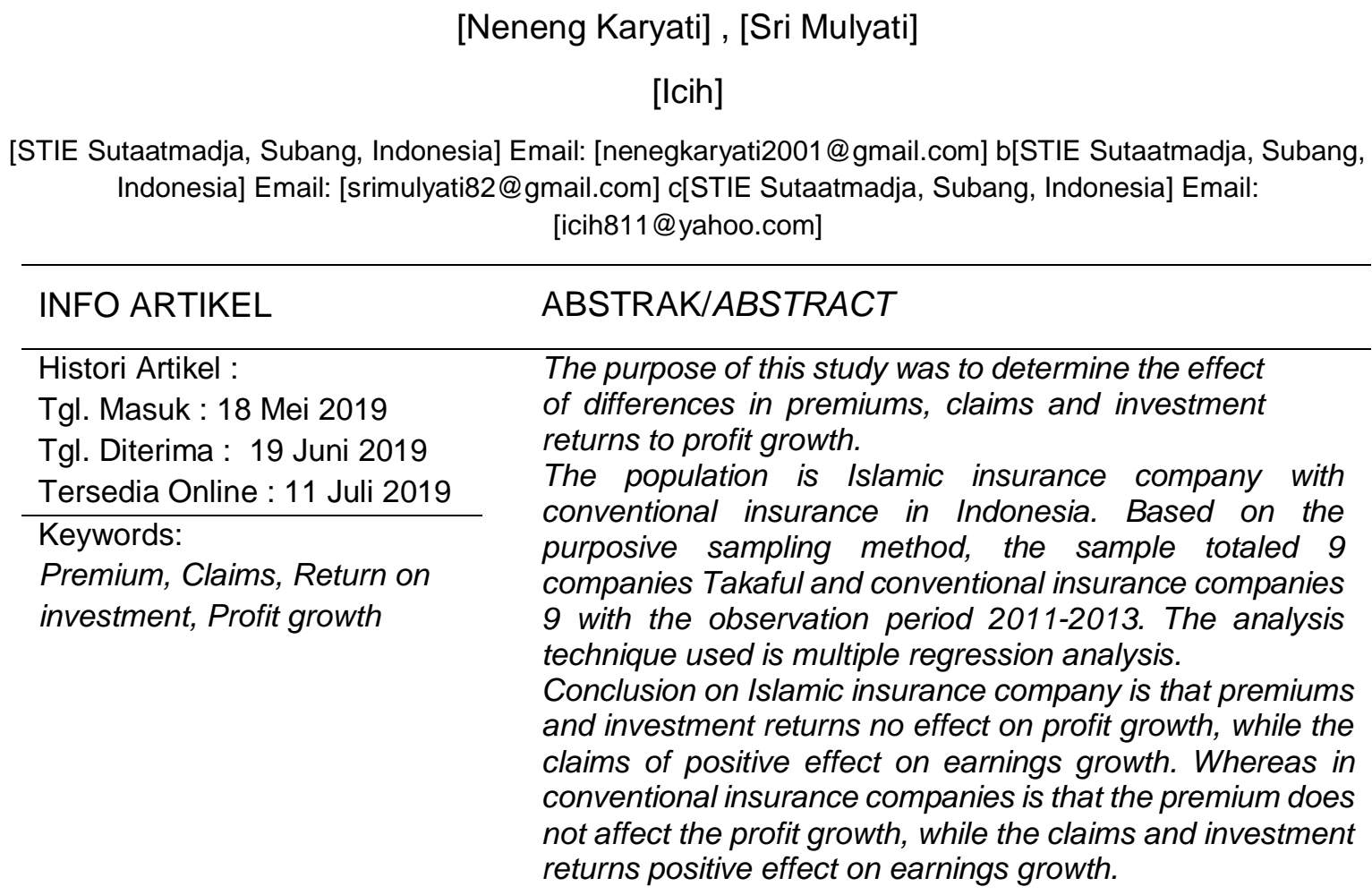

\section{PENDAHULUAN}

Setiap keputusan yang diambil manusia dalam menjalani kehidupannya selalu dipenuhi dengan resiko. Resiko adalah kemungkinan kerugian yang akan dialami yang diakibatkan oleh bahaya yang mungkin terjadi tetapi tidak diketahui lebih dahulu apakah akan terjadi dan kapan akan terjadi. Resiko-resiko tersebut bersifat tidak pasti, apakah akan terjadi dalam waktu dekat atau kemudian hari, apabila resiko tersebut betul-betul terjadi, tidak diketahui berapa kerugiannya secara ekonomis. Timbulnya resiko tersebut membuat manusia dalam menjalani kegiatan dan aktivitasnya diliputi oleh perasaan yang tidak nyaman dan aman. (Rony, 2011)
Manusia sebagai makhluk ciptaan Tuhan dengan akal budinya mencari cara agar ketidakpastian dalam hidupnya menjadi suatu kepastian. Salah satu cara mengatasi resiko tersebut adalah dengan cara mengalihkan resiko (risk transfer) kepada pihak lain diluar diri manusia. Pada saat ini pihak lain penerima risiko dan mampu mengelola tersebut adalah perusahaan asuransi. (Rony, 2011)

Asuransi pada hakikatnya adalah cara yang paling efisien dan efektif untuk mengganti penghasilan seseorang yang hilang penghasilannya. Asuransi jiwa mengganti pendapatan yang hilang pada saat kematian atau seseorang tidak mampu bekerja secara normal. Asuransi kesehatan digunakan sebagai cadangan untuk persiapan mengganti biaya 
pengobatan atau rawat inap di rumah sakit. Asuransi kerugian seperti halnya asuransi property yaitu membayar kehilangan yang disebabkan oleh kebakaran, pencurian, dan kecelakaan. (Ferry Rinaldi, 2014)

Pengertian asuransi telah tertuang dalam UU No.2 Tahun 1992 tentang Usaha Perasuransian, Asuransi adalah perjanjian antara dua pihak atau lebih dengan mana pihak penanggung mengikatkan diri kepada tertanggung, dengan menerima premi asuransi, untuk memberikan penggantian kepada tertanggung karena kerugian, kerusakan, atau kehilangan keuntungan yang diharapkan atau tanggung jawab hukum kepada pihak ketiga yang mungkin akan diderita tertanggung, yang timbul dari suatu peristiwa yang tidak pasti, atau untuk memberikan suatu pembayaran yang didasarkan atas meninggal atau hidupnya seseorang yang dipertanggungkan.

Perkembangan industri asuransi syariah di negeri ini diawali dengan kelahiran asuransi syariah pertama Indonesia pada 1994. Saat itu, PT Syarikat Takaful Indonesia (STI) berdiri pada 24 Februari 1994 sebagai holding company dari dua anak perusahaan, yaitu PT Asuransi Takaful Keluarga (24 Agustus 1994), PT Asuransi Takaful Umum (2 Juni 1995). Hal ini dimotori oleh Ikatan Cendekiawan Muslim Indonesia (ICMI) melalui Yayasan Abdi Bangsa, Bank Muamalat Indonesia, PT Asuransi Jiwa Tugu Mandiri, Departemen Keuangan RI, serta beberapa pengusaha Muslim Indonesia. Namun jika dilihat dari pertumbuhannya, maka selama periode 1994 s/d 1995, perkembangan asuransi syariah sangatlah menggembirakan. Dibanding dengan asuransi konvensional yang hanya mencapai rata-rata $20 \%$, pertumbuhan asuransi syariah bisa mencapai $40 \%$ dalam 5 tahun terakhir. Hal itu cukup menggambarkan bahwa peminat asuransi syariah semakin bertambah setiap tahunnya, walaupun pada akhir 2005 pangsa pasar asuransi syariah tercatat baru mencapai $1,5 \%$ dari total pasar asuransi di Indonesia. Melihat prospek yang sangat cerah ini, tak heran jika terutama sejak tahun 2003 banyak perusahaan asuransi konvensional yang membuka cabang syariah. Situasi ini juga terdorong oleh keluarnya KMK (keputusan menteri keuangan) terbaru tahun 2003 yang mengatur regulasi syariah.

Perusahaan asuransi syariah mendapatkan keuntungan usaha dari pembagian keuntungan dana peserta dengan prinsip mudharabah atau sistem bagi hasil. Keuntungan tersebut dibagi antara perusahaan dan peserta asuransi syariah berdasarkan nisbah atau ketentuan yang disepakati. Perusahaan asuransi syariah memperoleh laba dari pendapatan premi dan hasil investasi. Pendapatan premi diperoleh dari pembayaran yang wajib dilakukan oleh setiap peserta asuransi syariah yang dilakukan secara teratur kepada perusahaan asuransi syariah yang sesuai pada kesesuaian dalam akad. Pendapatan premi dan hasil investasi merupakan faktor penting bagi laba perusahaan asuransi syariah.

Laba merupakan elemen yang paling menjadi perhatian pengamat keuangan karena angka laba diharapkan cukup kaya untuk merepresentasikan kinerja perusahaan secara keseluruhan. Unsur-unsur dalam penbentukan laba adalah pendapatan, beban atau biaya. Laba dapat digolongkan menjadi beberapa jenis, yaitu laba kotor, laba opesional, laba sebelum pajak, dan laba bersih setelah pajak. (Ghazali 2001)

Pengukuran laba bukan saja penting untuk menentukan prestasi perusahaan tetapi juga penting sebagai informasi bagi pembagian laba dan penentuan kebijakan investasi. Oleh karena itu, laba menjadi informasi yang dilihat oleh banyak profesional seperti profesi akuntansi, pengusaha, analis keuangan, pemegang saham, ekonom, fisikus, dan sebagainya (Harahap, 2001, dalam Sabrina, 2013). 
Piranti umum dan terukur untuk evaluasi kinerja perusahaan asuransi adalah dengan melakukan analisis terhadap aspek-aspek kinerja perusahaan dalam laporan keuangannya yang merupakan muara dari seluruh aktivitas perusahaan (Fikri, 2009). Pada perusahaan asuransi, faktor-faktor yang digunakan untuk melihat apakah memiliki pengaruh yang signifikan terhadap laba diantaranya adalah premi, klaim dan investasi. Hal ini untuk mengetahui komponen -komponen mana dari laporan keuangan tersebut yang berpengaruh terhadap laba sehingga perusahaan dapat meninjau lebih lanjut kinerjanya agar mendapatkan laba yang optimal.

Premi adalah sejumlah uang yang harus dibayarkan setiap bulannya sebagai kewajiban dari tertanggung atas keikutsertaannya di asuransi. Besarnya premi atas keikutsertaan di asuransi yang harus di bayarkan telah di tetapkan oleh perusahaan asuransi dengan memperhatikan keadaan- keadaan dari tertanggung. Sedangkan klaim merupakan pengajuan hak yang di lakukan oleh tertanggung kepada penanggung untuk mendapatkan haknya berupa pertanggungan atas kerugian berdasarkan perjanjian atau akad yang telah dibuat. (Abdul Amin, 2006)

Investasi di dalam perusahaan asuransi dapat dirupakan dalam bentuk portofolio. Menurut Lawrence dan Michael yang dikutip oleh M. Syakir Sula, portofolio adalah kumpulan bentuk investasi terpadu yang bertujuan untuk mendapatkan keuntungan investasi. Tujuan utama portofolio investasi adalah mendapatkan tingkat pengembalian yang tinggi dengan tingkat risiko yang kecil untuk memenuhi kewajiban baik kepada pemegang polis maupun untuk pertumbuhan perusahaan.

Sedangkan pertumbuhan laba merupakan Ukuran pertumbuhan pendapatan perusahaan selama periode 1 tahun, dihitung dengan membagi perubahan pendapatan selama tahun fiskal terakhir oleh jumlah pendapatan pada awal tahun fiscal.

Penelitian ini menjadi penting untuk dilakukan karena laba merupakan nilai prestasi kesehatan keuangan suatu perusahaan dan kemampuan perusahaan dalam menjalankan kegiatan operasionalnya secara maksimal. Sehingga penting pengukuran pertumbuhan laba menjadi dasar bagi seorang menejemen untuk dapat memutuskan apakah perusahaan akan tetap dipertahankan atau akan ditingkatkan. Dengan pertumbuhan laba yang tinggi dapat menunjukkan bahwa perusahaan dapat mengoptimalkan kegiatan operasionalnya dengan baik, dengan demikian tingkat masyarakat terhadap perusahaan dapat terus dipertahankan serta ditingkatkan, sehingga perusahaan perlu melakukan pengawasan serta analisis terhadap pertumbuhan laba. Oleh karena itu, peneliti menganggap penting adanya penelitian mengenai pertumbuhan laba tersebut untuk dapat mengukur seberapa maksimal perusahan dalam malakukan kegiatan operasionalnya serta perolehan laba pada perusahaan asuransi, dalam penelitian ini adalah perusahaan asuransi syariah dan asuransi konvensional.

Berdasarkan uraian-uraian latar belakang diatas, maka penulis tertarik untuk melakukan penelitian mengenai "Analisis Perbedaan Pengaruh Premi, Klaim, Dan Investasi Terhadap Pertumbuhan Laba (Pada Perusahaan Asuransi Syariah Dengan Asuransi

Konvensional)". Penelitian ini bertujuan untuk mengetahui Bagaimana perbedaan pengaruh premi, klaim, dan investasi terhadap pertumbuhan laba pada perusahaan asuransi syariah dengan asuransi konvensional. 


\section{KERANGKA TEORITIS DAN PENGEMBANGAN HIPOTESIS}

\section{Pengertian Asuransi}

Asuransi pada hakikatnya adalah cara yang paling efisien dan efektif untuk mengganti penghasilan seseorang yang kehilangan penghasilannya. Asuransi Jiwa mengganti pendapatan yang hilang pada saat kematian atau seseorang tidak mampu bekerja secara normal. Asuransi kesehatan digunakan sebagai cadangan untuk persiapan mengganti biaya pengobatan atau rawat inap di rumah sakit. Asuransi kerugian, seperti halnya asuransi properti, yaitu membayar kehilangan yang disebabkan oleh, kebakaran, pencurian dan kecelakaan. Ada beberapa definisi asuransi sebagai berikut:

Menurut Kitab Undang-undang Hukum Dagang pasal 246

"Asuransi atau pertanggungan adalah suatu perjanjian, dengan mana seseorang penanggung mengikatkan diri pada seseorang tertanggung, dengan menerima suatu premi untuk memberikan penggantian kepadanya karena suatu kerugian, kerusakan, atau kehilangan keuntungan yang diharapkan, yang mungkin terjadi karena suatu peristiwa tak tertentu."

Menurut Undang-undang Nomor 2
Tahun 1992 tentang Usaha
Perasuransian "Asuransi atau
pertanggungan adalah perjanjian
antara dua pihak atau lebih, dengan
mana pihak penanggung mengikatkan
diri kepada tertanggung dengan
menerima premi asuransi, untuk
memberikan penggantian kepada
tertanggung karena kerugian,
kerusakan, atau kehilangan
keuntungan yang diharapkan atau
tanggung jawab hukum kepada pihak
ketiga yang mungkin akan diderita
tertanggung, yang timbul dari suatu
peristiwa yang tidak pasti, atau untuk

memberikan suatu pembayaran yang didasarkan atas meninggal atau hidupnya seseorang yang dipertanggungkan".

Menurut paham ekonomi "Asuransi merupakan suatu lembaga keuangan karena melalui asuransi dapat dihimpun dana besar, yang dapat digunakan untuk membiayai pembangunan, di samping bermanfaat bagi masyarakat yang berpartisipasi dalam bisnis asuransi, serta asuransi bertujuan memberikan perlindungan atau proteksi atas kerugian keuangan (financial loss), yang ditimbulkan oleh peristiwa yang tidak diduga sebelumnya (fortuitious event)"

\section{Asuransi Syariah}

Dalam bahasa arab asuransi disebut at-ta'min, penanggung disebut mu'ammin, sedangkan tertanggung disebut mu'amman lahu atau musta'min. mentaminkan sesuatu, artinya adalah seseorang membayar atau menyerahkan uang ciciln agar ahli warisnya mendapatkan ganti terhadap hartanya yang hilang (ibid,:12).

Husain hasim hisam mengatakan bahwa asuransi adalah sikap ta'awun yang telah diatur dengan sistem yang sangat rapih, antara sejumlah besar manusia. Semuanya telah siap mengantisipasi suatu peristiwa. Jika sebagian mereka mengalami pristiwa tersebut, maka semuanya saling menolong dalam menghadapi peristiwa tersebut dengan sedikit pemberian (derma) yang diberikan oleh masingmasing peserta. Dengan pemberian (derma) tersebut, mereka dapat menutupi kerugian-kerugian yang dialami oleh peserta yang tertimpa musibah. Dengan demikian, asuransi adalah ta'awun yang terpuji yaitu saling menolong dalam berbuat kebajikan dan takwa, dengan demikian ta'awun mereka saling membantu antar sesama, dan mereka takut dengan bahaya (malapetaka) yang mengancam mereka (ibid:29). 


\section{Asuransi Konvensional}

Kata asuransi berasal dari bahasa belanda, assurantie, yang dalam hukum belanda disebut verzekering yang artinya pertanggungan. Dari peristilahan assurantie kemudian timbul istilah assuradeur bagi penanggung dan greassureerde bagi tertanggung (Muhammad syakir sula).

Asuransi Konvensional pada dasarnya ialah Proses Mentransfer Resiko (Risk Transfering), dalam hal ini ialah Resiko keuangan yang mungkin terjadi apabila seseorang terkena musibah meninggal/sakit kritis/cacat tetap total. Resiko keuangan yang seharusnya ditanggung oleh keluarga akan ditanggung oleh perusahaan asuransi dengan cara orang tersebut membayar sejumlah besar premi yang telah ditentukan. Semua keuntungan/kerugian akan ditanggung oleh perusahaan asuransi yang mengelolanya (sagalawira, 2013).

\section{Pengertian Laba}

Pada umumnya, ukuran yang sering kali digunakan untuk menilai berhasil atau tidaknya manajemen suatu perusahan adalah dengan melihat laba yang diperoleh perusahaan. laba sebagai jumlah yang berasal dari pengurangan harga pokok produksi, biaya lain dan kerugian dari penghasilan atau penghasilan operasi (Aliyal Azmi 2007:12) laba adalah pengambilan atas investasi kepada pemilik. Hal ini mengukur nilai yang dapat diberikan oleh entitas kepada investor dan entitas masih memiliki kekayaan yang sama dengan posisi awalnya (Stice, Skousen 2009:240) Sedangkan pengertian laba menurut Suwardjono (2008 464) adalah sebagai berikut:

"Laba dimaknai sebagai imbalan atas upaya perusahaan menghasilkan barang dan jasa. Ini berarti laba merupakan kelebihan pendapatan diatas biaya (biaya total yang melekat kegiatan produksi dan penyerahan barang / jasa)."=
Menurut Ghazali (2001), unsurunsur laba antara lain :

1. Pendapatan adalah aliran masuk atau kenaikkan aktiva suatu perusahaan atau penurunan kewajiban yang terjadi dalam suatu periode akuntansi, yang berasal dari aktivitas operasi dalam hal ini penjualan barang (kredit) yang merupakan unit usaha pokok perusahaan.

2. Beban (expense) adalah penurunan manfaat ekonomi selama suatu periode akuntansi dalam bentuk arus keluar atau berkurangnya aktiva atau terjadinya kewajiban yang mengakibatkan penurunan ekuitas yang tidak menyangkut pembagian kepada penanam modal.

3. Biaya adalah kas atau nilai equivalen kas yang dikorbankan untuk barang atau jasa yang diharapkan membawa keuntungan masa ini dan masa datang untuk organisasi. Biaya yang telah kadaluarsa disebut beban, tiap periode beban dikurangkan dari pendapatan pada laporan keuangan rugi-laba untuk menentukan laba periode.

4. Keuntungan adalah kenaikkan ekuitas atau aktiva bersih yang berasal dari transaksi insidental yang terjadi pada perusahaan dan semua transaksi atau kejadian yang mempengaruhi perusahaan dalam suatu periode akuntansi selain yang berasal dari pendapatan investasi pemilik.

\section{Jenis-jenis Laba}

Hansen dan Mowen (2001), mengkategorikan laba menjadi beberapa jenis, yaitu:

1. Laba kotor adalah selisih dari hasil penjualan dengan harga pokok penjualan

2. Laba Operasional merupakan hasil dari aktivitas-aktivitas yang termasuk rencana perusahaan kecuali ada perubahan-perubahan besar dalam perekonomiannya, dapat diharapkan akan dicapai setiap tahun. Oleh karenanya, angka ini menyatakan 
kemampuan perusahaan untuk hidup dan mencapai laba yang pantas sebagai jasa pada pemilik modal.

3. Laba sebelum dikurangi pajak atau EBIT (Earning Before Tax) merupakan laba operasi ditambah hasil dan biaya diluar operasi biasa. Bagi pihak-pihak tertentu terutama dalam hal pajak, angka ini adalah yang terpenting karena jumlah ini menyatkan laba yang pada akhirnya dicapai perusahaan.

4. Laba Setelah Pajak Atau Laba Bersih adalah laba setelah dikurangi berbagai pajak. Laba dipindahkan kedalam perkiraan laba ditahan. Dari perkiraan laba ditahan ini akan diambil sejumlah tertentu untuk dibagikan sebagai Deviden kepada para pemegang saham.

\section{Tujuan Pelaporan Laba}

Menurut Suwardjono, (2005:456) Laba akuntansi dengan berbagai interpretasinya diharapkan dapat digunakan antara lain sebagai:

1. Indikator efisiensi penggunaan dana yang tertanam dalam perusahaan yang diwujudkan dalam tingkat kembalian atas investasi (rate of retun on inuested capital).

2. Pengukur prestasi atau kinerja badan usaha dan manajemen.

3. Dasar penentuan besarnya pengenaan pajak.

4. Alat pengendalian alokasi sumber daya ekonomik suatu negara.

5. Dasar penentuan dan penilaian kelayakan tarif dalam perusahaan publik.

6. Alat pengendalian terhadap debitor dalam kontrak utang.

7. Dasar kompensasi dan pembagian bonus.

8. Alat motivasi manajemen dalam pengendalian perusahaan.

9. Dasar pembagian dividen.
Chariri dan Ghozali (2003:214) menyebutkan bahwa laba memiliki beberapakarakteristik, antara lain sebagai berikut:

1) Laba didasarkan pada transaksi yang benar-benar terjadi

2) Laba didasarkan pada postulat periodisasi, artinya merupakan prestasiperusahaan pada periode tertentu

3) Laba didasarkan pada prinsip pendapatan yang memerlukan pemahaman khusustentang definisi, pengukuran dan pengakuan pendapatan

4) Laba memerlukan pengukuran tentang biaya dalam bentuk biaya historis yangdikeluarkan perusahaan untuk mendapatkan pendapatan tertentu

5) Laba didasarkan pada perinsip penandingan (matching) antara pendapatan dan biaya yang relevan dan berkaitan dengan pendapatan tersebut.

Perbandingan yang tepat atas pendapatan dan biaya tergambar dalam laporan laba rugi. Penyajian laba melalui laporan tersebut merupakan fokus kinerja perusahaan yang penting. Kinerja perusahaan merupakan hasil dari serangkaian proses dengan mengorbankan berbagai sumber daya. Adapun salah satu parameter penilaian kinerja perusahaan tersebut adalah pertumbuhan laba. pertumbuhan laba dihitung dengan cara mengurangkan laba periode sekarang dengan laba periode sebelumnya kemudian dibagi dengan laba pada periode sebelumnya (warsidi dan pramuka,2000).

Pertumbuhan Laba $=$

Laba bersuh tahun $(t)-$ laba bersih tahun $(t-1)$ Laba bersih tahun $(t-1)$ 


\section{Premi}

Dalam pasal 246 KUHD terdapat rumusan sebagai berikut :

\begin{abstract}
"dengan mana penanggung mengikatkan diri kepada tertanggung dengan menerima premi".Berdasarkan rumusan tersebut, dapat diketahui bahwa premi adalah salah satu unsur penting dalam asuransi karena merupakan kewajiban utama yang wajib dipenuhi oleh tertanggung kepada penanggung."
\end{abstract}

Dalam hubungan hukum asuransi ini, penanggung menerima pengalihan resiko dari tertanggung dan tertanggung membayar sejumlah premi sebagai imbalannya. Namun jika premi tidak dibayar, asuransi tersebut dapat dibatalkan atau setidak-tidaknya asuransi tidak akan berjalan. Premi asuransi ini harus dibayar lebih dahulu oleh tertanggung karena tertanggunglah pihak yang berkepentingan.Premi asuransi merupakan syarat mutlak untuk menetukan perjanjian asuransi dilaksanakan atau tidak. Kreteria premi asuransi yaitu : (a) dalam bentuk sejumlah uang, (b) dibayar lebih dahulu oleh si tertanggung,(c) sebagai imbalan pengalihan resiko,(d) perhitungan berdasarkan persentase terhadap nilai resiko yang dialihkan.

\section{Klaim}

Menurut PSAK No. 28 klaim adalah ganti rugi yang dibayarkan atau yang menjadi kewajiban kepada tertanggung atau perusahaan asuransi (ceding company) sehubungan dengan telah terjadinya kerugian.

Klaim adalah pengajuan hak yang dilakukan oleh tertanggung kepada penanggung untuk mendapatkan haknya berupa pertanggungan atas kerugian berdasarkan perjanjian atau akad yang telah di buat. Dengan kata lain, klaim adalah proses pengajuan oleh peserta untuk mendapatkan uang pertanggungan setelah tertanggung melaksanakan seluruh kewajibannya kepada penanggung, yaitu berupa penyelesaian pembayaran premi sesuai dengan kesepakatan sebelumnya. (Abdul Amin, 2006).

\section{Investasi}

Menurut Lawrence \& Michael (Sula, 2004:379), suatu portofolio adalah kumpulan bentuk investasi yang terpadu untuk tujuan mendapatkan keuntungan investasi. Tujuan utama dari pembentukan suatu portofolio adalah tidak lain untuk mendapatkan hasil yang optimal dengan resikoyang minimal. Hasil investasi tersebut diperoleh dari penanaman modal dengan melakukan diversifikasi portofolio untuk mendapatkan perolehan bagi hasil yang optimum. Hasil investasi memegang peranan penting bagi pendapatan perusahaan asuransi syariah.

\section{Hipotesis}

Penelitian yang dilakukan Dian Astria (2009) yang berjudul"Analisis Faktor-Faktor yangMempengaruhi Laba Asuransi Takaful Keluarga." Penelitian ini menggunakan analisis metode Ordinary Least Square (OLS). Variabel independen yang di gunakan adalah penerimaan premi, beban klaim, hasil investasi, beban operasional dan krisis ekonomi dengan laba sebagai variabel dependen.

Hasil penelitiannya menunjukkan bahwa penerimaan premi dan hasil investasi memiliki pengaruhyang positif dan signifikan terhadap laba asuransi takaful keluarga Sedangkanbeban klaim, beban opersional, dan krisis ekonomi memiliki pengaruh negatif dansignifikan terhadap laba asuransi takaful keluarga.

M. Agung Ali Fikri (2009) melakukan sebuah penelitian dengan judul "Pengaruh premi, klaim, hasil investasi, dan underwriting terhadap laba asuransi jiwa syariah (studi kasus: PT Asuransi Syariah Mubarakah)". Variable dependen yang di gunakan adalah laba dengan variable Independennya premi, klaim, hasil investasi, dan underwriting. Data dianalisis dengan menggunakan model analisis regresi berganda. 
Hasil penelitian menunjukan bahwa Pendapatan premi dan klaim berpengaruh negatif terhadap laba asuransi syariah Mubarakah.Hasil investasi dan surplus underwriting berpengaruh positif terhadap laba asuransi syariah mubarakah.

Sebuah penelitian yang berjudul "Analisis pengaruhpendapatan asuransi jiwa terhadap tingkat rentabilitas dan laba pada PT AsuransiJiwasraya (Persero) periode 2008-2012." Yang dilakukan oleh Septianawati (2012). Analisis data yang digunakan adalah Analisis regresi berganda. Hasil penelitiannya adalah analisispengaruh dan hubungan pendapatan premi terhadap rentabilitas pada PT AsuransiJiwasraya untuk periode 2008-2012 tidak terdapat hubungansignifikan antara pendapatan premi terhadap rentabilitas ekonomi PT. AsuransiJiwasraya periode 2008-2012. Analisis pengaruh dan hubungan pendapatan premiterhadap laba pada PT. Asuransi Jiwasraya untuk periode 2008 2012 tidak terdapat hubungan signifikan antara pendapatan premi terhadap labapada PT. Asuransi Jiwasraya untuk periode 2008-2012.

Penelitian yang dilakukan Mutmainah dengan judul "Analisis Pengaruh Pendapatan Premi, Beban Klaim, Hasil Underwriting, Cadangan Teknis, Dan Risk Based Capital Terhadap Laba Pada 20 Perusahaan Asuransi Umum Di Indonesia Periode 2009-2013". Penelitian ini menggunakan metode analisis dengan model regresi linier berganda. Dari hasil uji $\mathrm{F}$ menunjukkan bahwa pendapatan premi, beban klaim, hasil underwriting, cadangan teknis, dan Risk Based Capital secara simultan atau bersama-sama berpengaruh signifikan terhadap laba. Dan berdasarkan hasil uji $\mathrm{T}$ menunjukkan bahwa pendapatan premi, hasil underwriting, cadangan teknis, dan Risk Based Capital secara parsial atau masing-masing berpengaruh positif signifikan terhadap laba, sedangkan beban klaim secara parsial tidak berpengaruh signifikan terhadap laba.
Beberapa penelitian menunjukkan hasil penelitian yang berbeda yaitu, pendapatan premi berpengaruh negatif dan tidak mempunyai hubungan signifikanterhadap laba. Karena adanya perbedaan hasil penelitian ini, penulis ingin mengujikembali variabel tersebut dengan menambahkan beberapa variabel. Pada penelitian ini digunakan variabel terikat dan variabel bebas. Variabel terikat(dependen) yang digunakan adalah pertumbuhan laba. Sedangkan variabel bebas (independen) yang digunakan adalah premi, klaim, dan investasi. 


\section{METODOLOGI PENELITIAN}

\section{Jenis, Sumber Data dan Teknik Pengumpulan Data}

Jenis data yang digunakan oleh peneliti merupakan data sekunder. Sumber data yang digunakan dalam penelitian ini adalah berupa laporan keuangan tahunan perusahaan asuransi syariah dengan asuransi konvensional yang ada di indonesia. Untuk memperoleh data yang diperlukan dalam penelitian ini, teknik pengumpulan data yang digunakan adalah studi dokumentasi dan studi kepustakaan.

\section{Populasi dan Sampel}

Populasi adalah wilayah
generalisasi yang terdiri atas obyek/subyek yang mempunyai kualitas dan karakteristik tertentu yang ditetapkan oleh peneliti untuk dipelajari dan kemudian ditarik kesimpulannya (Sugiyono, 2012:80). Adapun populasi dari penelitian ini adalah perusahaan asuransi syariah dan konvensional yang ada Indonesia.

Berdasarkan penjelasan diatas, untuk membuktikan kebenaran jawaban yang masih sementara (hipotesis), maka penulis melakukan pengumpulan data pada objek tertentu. Karena objek dalam populasi terlalu luas, maka peneliti menggunakan sampel yang diambil dari populasi tersebut.

\section{Teknik Pemilihan Sampel}

Teknik pemilihan sampel yang diterapkan adalah nonprobability sampling yaitu teknik pengambilan sampel yang tidak memberi peluang yang sama bagi setiap anggota populasi untuk dijadikan sampel. Sedangkan metode sampel yang dipilih adalah purposive sampling. Purposive sampling merupakan mtode penetapan sampel dengan berdasarkan kriteria-kriteria tertentu (Suliyanto, 2012). Maka kriteria-kriteria yang harus dipenuhi untuk dijadikan sampel dalam penelitian ini adalah sebagai berikut:

1. Perusahaan asuransi syariah dan asuransi konvensional di Indonesia yang aktif beroprasi pada tahun 20112013

2. Perusahaan yang telah mempublikasikan laporan keuangan tahunan (annual report) pada tahun 2011-2013 dan memiliki data lengkap mengenai variabel yang diteliti.

\section{Variabel Independen (X)}

Variabel independen atau yang sering disebut juga variabel bebas adalah variabel yang mempengaruhi atau yang menjadi sebab perubahan atau timbulnya variabel dependen (terikat) (Sugiyono, 2012:39). Variabel independen dalam penelitian ini terdiri dari:

1. Premi

Premi merupakan pembayaran sejumlah uang yang dilakukan pihak tertanggung kepada penanggung untuk mengganti suatu kerugian, kerusakan, atau kehilangan keuntungan yang diharapkan akibat timbulnya perjanjian atas pemindahan risiko dari tertanggung kepada penanggung (transfer of risk). (Abdul Amin, 2006). Dalam penelitian ini, premi yang digunakan adalah jumlah pendapatan premi yang terdapat di laporan keuangan (Abdul Amin, 2006).

2. Klaim

Klaim adalah pengajuan hak yang dilakukan oleh tertanggung kepada penanggung untuk mendapatkan haknya berupa pertanggungan atas kerugian berdasarkan perjanjian atau akad yang telah di buat. Dengan kata lain, klaim adalah proses pengajuan oleh peserta untuk mendapatkan uang pertanggungan setelah tertanggung melaksanakan seluruh kewajibannya kepada penanggung, yaitu berupa penyelesaian pembayaran premi sesuai dengan kesepakatan sebelumnya(Abdul Amin, 2006). Dalam penelitian ini, klaim yang digunakan adalah utang klaim yang terdapat di laporan keuangan (Abdul Amin, 2006).

3. Investasi 
Investasi ialah penanaman modal yang dilakukan oleh investor, baik investor asing maupun domestik dalam berbagai bidang usaha yang terbuka untuk investasi, yang bertujuan untuk memperoleh keuntungan (Salim HS dan Budi Sutrisno). Menurut Lawrence \& Michael (Sula, 2004:379), investasi dalam perusahaan asuransi dapat dirupakan dalam bentuk suatu portofolio yang artinya adalah kumpulan bentuk investasi yang terpadu untuk tujuan mendapatkan keuntungan investasi. Tujuan utama dari pembentukan suatu portofolio adalah tidak lain untuk mendapatkan hasil yang optimal dengan resiko yang minimal. Hasil investasi tersebut diperoleh dari penanaman modal dengan melakukan diversifikasi portofolio untuk mendapatkan perolehan bagi hasil yang optimum. Hasil investasi memegang peranan penting bagi pendapatan perusahaan asuransi syariah. Dalam penelitian ini, investasi yang digunakan adalah hasil investasi yang terdapat di laporan keuangan.

\section{Variabel Dependen (Y)}

Variabel dependen atau yang sering disebut juga variabel terikat adalah variabel yang dipengaruhi atau yang menjadi akibat karena adanya variabel bebas (Sugiyono, 2012:39). Variabel indenpenden dalam penelitian ini adalah Pertumbuhan Laba.

Perbandingan yang tepat atas pendapatan dan biaya tergambar dalam laporan laba rugi. Penyajian laba melalui laporan tersebut merupakan fokus kinerja perusahaan yang penting. Kinerja perusahaan merupakan hasil dari serangkaian proses dengan mengorbankan berbagai sumber daya.

Pertumbuhan Laba $=$

Laba bersuh tahun $(t)-$ laba bersih tahun $(t-1)$ Laba bersih tahun $(t-1)$

Adapun salah satu parameter penilaian kinerja perusahaan tersebut adalah pertumbuhan laba. pertumbuhan laba dihitung dengan cara mengurangkan laba periode sekarang dengan laba periode sebelumnya kemudian dibagi dengan laba pada periode sebelumnya (warsidi dan pramuka,2000).

\section{Metode Analisis Data}

\section{Analisis Statistik Deskriptif}

Stastistik deskriptif memberikan gambaran atau deskripsi suatu data yang dilihat dari nilai rata- rata (mean), Median, Modus, Standar Deviasi. Analisis statistik deskriptif digunakan untuk melihat kenderungan dari masing-masing variabel penelitian.

\section{Uji Asumsi Klasik}

Pengujian asumsi klasik diperlukan untuk mengetahui apakah hasil estimasi regresi yang dilakukan benar-benar bebas dari adanya gejala heterokedastisitas, gejala multikolinearitas dan gejala problem autokorelasi. (Ghozali, 2013).

\section{Uji Normalitas}

Uji normalitas bertujuan untuk menguji apakah dalam model regresi, variabel pengganggu atau residual memiliki distribusi normal (Ghazali, 2013:160). Model distribusi data yang normal atau mendekati normal dikatakan model regresi yang baik.. Uji Normalitas dalam penelitian ini dilakukan dengan menggunakan normalitas probability plot dengan melihat penyabaran data (titik-titik) pada sumbu diagonal pada grafik serta dengan melihat grafik histogram.

\section{Uji Multikoliniaritas}

Uji Multikoliniearitas bertujuan untuk menguji apakah model regresi ditemukan adanya korelasi antar variabel bebas (independen). Model regresi yang baik seharusnya tidak terjadi korelasi diantara variabel independen. Untuk mendeteksi adanya multikolonieritas dapat dilihat dari nilai Variance Inflation Factor (VIF) dan Tolerance. Multikolinieritas terjadi apabila nilai VIF $\geq 10$ dengan nilai Tolerance $\leq$ 
0.10 (Ghozali, 2013:105). Jadi suatu model regresi dikatakan tidak terjadi multikolinieritas apabila nilai VIF kurang dari 10 dan nilai tolerance lebih dari 0.1 .

\section{Uji Heteroskedastisitas}

Uji Heteroskedastisitas bertujuan untuk menguji apakah dalam model regresi terjadi ketidaksamaan variance dari residual satu pengamatan ke pengamatan yang lain. Model regresi yang baik seharusnya tidak terjadi heteroskedatisitas. Salah satu cara untuk mendeteksi adanya heteroskedastisitas adalah dengan melihat grafik plot antara nilai prediksi variabel terikat (ZPRED) dengan residualnya (SRESID). Dimana sumbu $Y$ adalah $Y$ yang telah diprediksi, dan sumbu $X$ adalah residual ( $Y$ prediksi $Y$ sesungguhnya) yang telah distudentized. Jika ada pola tertentu, seperti titik-titik yang ada membentuk pola tertentu yang teratur (misalnya bergelombang, melebar kemudian menyempit), maka mengindikasikan telah terjadi heteroskedasitas. Sebaliknya, jika tidak ada pola yang jelas, maka tidak terjadi heteroskedasitas dalam model regresi (Ghazali, 2013:139).

\section{Uji Autokorelasi}

Uji Autokorelasi bertujuan menguji apakah dalam model regresi linear ada korelasi antara kesalahan pengganggu pada periode $t$ dengan kesalahan pengganggu pada periode $\mathrm{t}-1$ (sebelumnya) (Ghazali, 2013:110).

\section{Analisis Regresi Berganda}

Model analisis yang digunakan adalah analisis regresi linear berganda karena penelitian ini dirancang untuk meneliti variabel dependen yang dipengaruhi oleh lebih dari satu variabel independen, Adapun persamaan regresi berganda secara statistik adalah sebagai berikut:

$$
Y=a+b 1 X 1+b 2 X 2+b 3 X 3+e
$$

Keterangan:

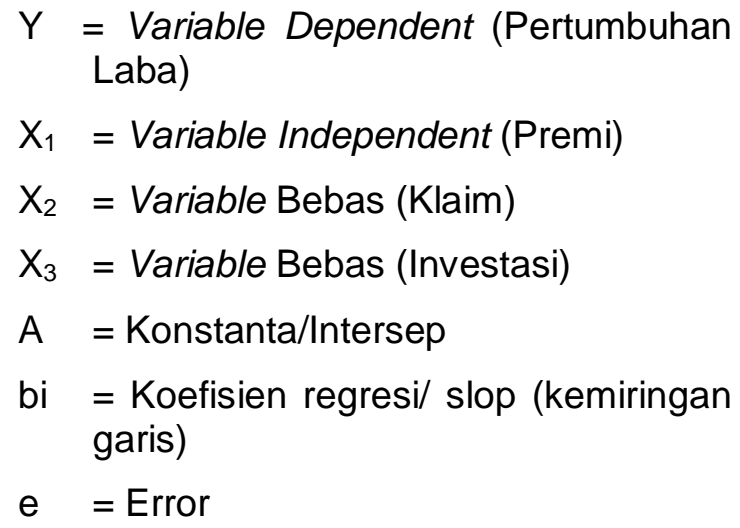

\section{Pengujian Hipotesis}

Uji hipotesis dilakukan untuk memperoleh gambaran mengenai hubungan antara variabel independen dengan variabel dependen. Hipotesis nol (Ho) menunjukan tidak adanya pengaruh yang signifikan antara variabel independen dan variabel dependen, Hipotesis penelitian (Ha) menunjukan adanya pengaruh yang signifikan antara variabel independendan variabel dependen.

\section{Uji Signifikansi Parameter Individual (Uji Statistik t)}

Uji statistik $t$ pada dasarnya menunjukkan seberapa jauh pengaruh satu variabel penjelas atau independen secara individual dalam menerangkan variasi variabel dependen (Fikriningrum, 2012). Uji statistik t digunakan untuk mengetahui ada tidaknya pengaruh secara linier antara variabel bebas dan variabel terikat. Uji t dapat juga dilakukan dengan melihat nilai signifikansi t masingmasing variabel pada output hasil regresi menggunakan SPSS 18 dengan significance level 0,05 $(\alpha=5 \%)$. Apabila nilai signifikansi lebih besar dari a maka hipotesis ditolak (koefisien regresi tidak signifikan), yang berarti secara individual variabel independen tidak mempunyai pengaruh yang signifikan terhadap variabel variabel dependen. Sebaliknya apabila nilai signifikansi lebih kecil dari $\alpha$ maka hipotesis diterima (koefisien regresi signifikan), berarti secara individual variabel independen mempunyai 
pengaruh yang signifikan terhadap variabel dependen (Kusumadilaga, 2010).

\section{Uji Signifikansi Simultan (Uji Statistik F)}

Uji Signifikansi Simultan atau yang lebih dikenal dengan Uji statistik $\mathrm{F}$, yaitu uji untuk melihat bagaimanakah pengaruh semua variabel bebasnya secara bersamasama terhadap variabel terikatnya atau untuk menguji apakah model regresi yang kita buat baik/signifikan atau tidak baik/non signifikan. Jika model signifikan maka model bisa digunakan untuk prediksi/peramalan, sebaliknya jika non/tidak signifikan maka model regresi tidak bisa digunakan untuk peramalan.

Uji $F$ dapat dilakukan dengan membandingkan statistik $\mathrm{F}$ hitung dengan statistik $F$ tabel. Jika statistik $t$ hitung < statistik $\mathrm{t}$ tabel maka Ho diterima dan jika statistik t hitung > statistik $\mathrm{t}$ tabel maka $\mathrm{Ha}$ diterima. Statistik tabel yang digunakan adalah tingkat signifikan ( $\alpha$ ) adalah 0,05 dan df $=\mathrm{n}-\mathrm{k}-1$

\section{Koefisien Determinasi}

Koefesien diterminasi $\left(R^{2}\right)$ pada
intinya mengukur seberapa jauh
kemampuan dariabel-variabel
independen dalam menerangkan
variasi variabel dependen. Nilai
koefesien determinasi adalah antara
nol sampai dengan satu. Nilai $R^{2}$ yang
kecil berarti kemampuan variabel-
variabel independen dalam
menjelaskan variasi variabel dependen
amat terbatas. Nilai yang mendekati
satu berarti variabel-variabel
independen memberikan hampir
semua informasi yang dibutuhkan
untuk untuk memprediksi variasi
variabel dependen.

Kelemahan mendasar penggunaan koefisien determinasi adalah bias terhadap jumlah variabel independen yang dimasukkan ke dalam model. Setiap tambahan satu variabel independen, maka $R^{2}$ pasti meningkat tidak peduli apakah variabel tersebut berpengaruh secara signifikan atau tidak terhadap variabel dependen. Oleh karena itu banyak peneliti yang menganjurkan untuk menggunakan nilai Adjusted $R^{2}$ pada saat mengevaaluasi mana model regresi terbaik (Ghazali, 2013:97). 


\section{HASIL DAN PEMBAHASAN}

\section{Uji Statistik Deskriptif}

\section{Descriptive Statistics}

\begin{tabular}{|l|c|c|c|c|c|c|}
\hline & $\mathrm{N}$ & Range & Minimum & Maximum & Mean & $\begin{array}{c}\text { Std. } \\
\text { Deviation }\end{array}$ \\
\hline PREMI & 27 & 6.57 & 15.38 & 21.95 & 18.6915 & 2.06696 \\
\hline KLAIM & 27 & 8.97 & 8.85 & 17.82 & 14.4081 & 2.50842 \\
\hline INVESTASI & 27 & 5.91 & 14.01 & 19.92 & 16.4230 & 1.65936 \\
\hline PERTUMBUHAN_LABA & 27 & 374.64 & -357.31 & 17.33 & 12.3381 & 69.02310 \\
\hline Valid N (listwise) & 27 & & & & & \\
\hline
\end{tabular}

Sumber: Data Output SPSS 
Dari 4.13 dapat diketahui bahwa jumlah sampel dalam penelitian ini adalah 27 sampel. Penjelasan dari masing-masing variabel adalah sebagai berikut:

1. Pertumbuhan laba $(Y)$ sebagai variabel dependen mempunyai nilai maximum sebesar 37 dan nilai minimum sebesar -04. Sehingga didapat range sebesar 41. Rata-rata variabel $Y$ ini adalah 0574 dengan nilai standar deviasi sebesar 0.9855 .

2. Premi (X1) mempunyai nilai maksimum sebesar 27.31 dan nilai minimum sebesar 18.98 sehingga didapat range sebesar 8.33. Rata-rata variabel ini adalah 25.1726 dengan nilai standar deviasi sebesar 2.72768 .

3. Klaim (X2) mempunyai nilai maksimum sebesar 24.88dan nilai minimum sebesar 18.37sehingga didapat nilai range sebesar 6.51. Rata-rata variabel ini adalah 22.6567 dengan nilai standar deviasi sebesar 1.40165

4. Investasi (X3) mempunyai nilai maksimum sebesar 27.57 dan nilai minimum 5.70 sehingga didapat range sebesar 5.70. Rata-rata variabel ini adalah 23.8752dengan nilai standar deviasi sebesar 1.2887.

\section{Uji Asumsi Klasik}

Untuk menghasilkan suatu model yang baik, maka analisis regresi memerlukan pengujian asumsi klasik sebelum melakukan pengujian hipotesis, pengujian asumsi klasik tersebut melalui:

1. Perusahaan Asuransi Syariah

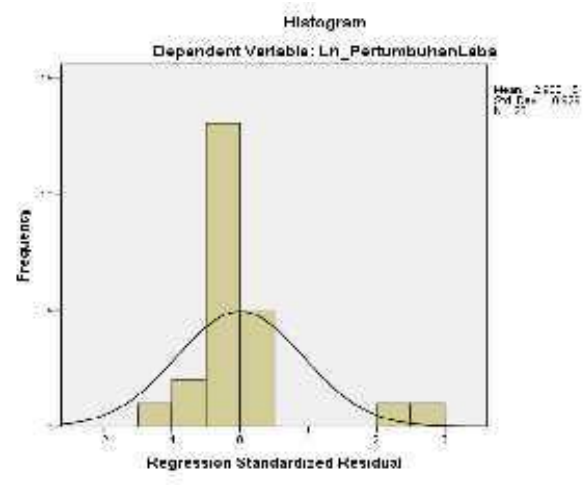

2. Perusahaan Asuransi Konvensional

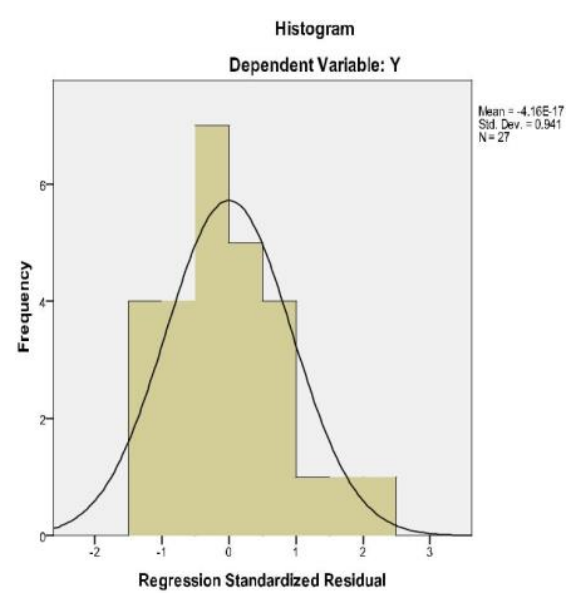

Berdasarkan

gambar

menunjukkan bahwa grafik pertumbuhan laba mengikuti distribusi normal dengan bentuk histogram yang hampir sama dengan bentuk distribunormal, hal ini berarti bahwa data residual terdistribusi secara normal.

1. Perusahaan Asuransi Syariah

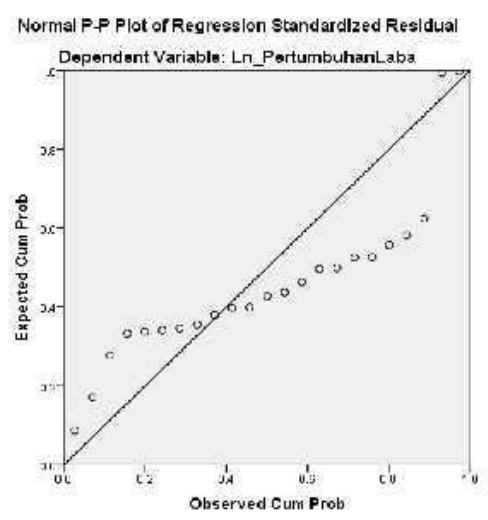

2. Perusahaan Asuransi Konvensional Normal P-P Plot of Regression Standardized Residual Dependent Variable: $Y$

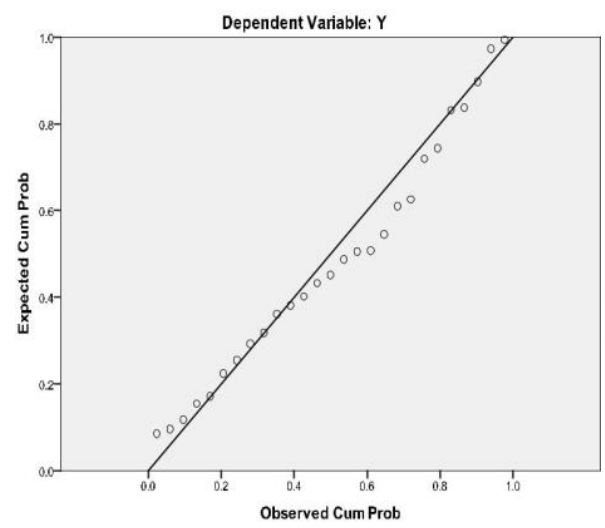


Berdasarkan

gambardiatas menunjukan bahwa titik-titik data berada disekitar garis diagonal dan sebagian ada yang agak menjauh. Sehingga dapat disimpulkan bahwa data ini mendekati normal.

\section{Uji Multikolinearitas}

Perusahaan Asuransi Syariah

\begin{tabular}{|r|r|r|}
\multicolumn{1}{c|}{ Coefficients $^{\mathbf{a}}$} \\
& \multicolumn{2}{|c|}{ Collinearity Statistics } \\
\cline { 2 - 3 } 1 (constant) & \multicolumn{1}{c|}{ Tolerance } & \multicolumn{1}{c|}{ VIF } \\
PREMI & .118 & 8.469 \\
\hline 2 KLAIM & .341 & \\
INVESTASI & .095 & 2.929 \\
\hline a. Dependent Variable: Ln_PertumbuhanLaba \\
\hline
\end{tabular}

Sumber: Data Output SPSS

Uji multikolinearitas bertujuan untuk menguji apakah dalam model regresi ditemukannya adanya korelasi antar variabel independen. Multikolinieritas dapat terjadi apabila nilai VIF lebih dari 10 dan nilai Tolerance kurang dari 0.1.Dari tabel di atas dapat diketahui bahwa nilai Tolerance dari semua variabel independen melebihi 0.1 dengan nilai VIF kurang dari 10. Hal ini menjelaskan bahwa tidak ada multikolinieritas antar variabel independen dalam model regresi.

\section{Perusahaan Asuransi Konvensional}

\begin{tabular}{|c|l|l|}
\hline \multirow{2}{*}{ Model } & \multicolumn{2}{|c|}{ Collinearity Statistics } \\
\cline { 2 - 3 } & Tolerance & \multicolumn{1}{c|}{ VIF } \\
\hline 1 (constant) & & \\
X1 & .382 & 2.618 \\
X2 & .922 & 1.085 \\
X3 & .394 & 2.540 \\
\hline
\end{tabular}

a. Dependent Variable: $Y$

Sumber: Data Output SPSS
Uji multikolinearitas bertujuan untuk menguji apakah dalam model regresi ditemukannya adanya korelasi antar variabel independen. Multikolinieritas dapat terjadi apabila nilai VIF lebih dari 10 dan nilai Tolerance kurang dari 0.1.Dari tabel di atas dapat diketahui bahwa nilai Tolerance dari semua variabel independen melebihi 0.1 dengan nilai VIF kurang dari 10. Hal ini menjelaskan bahwa tidak ada multikolineritas antar variabel independen dalam model regresi.

Hasil Uji Heteroskedastisitas

\section{Perusahaan Asuransi Syariah}

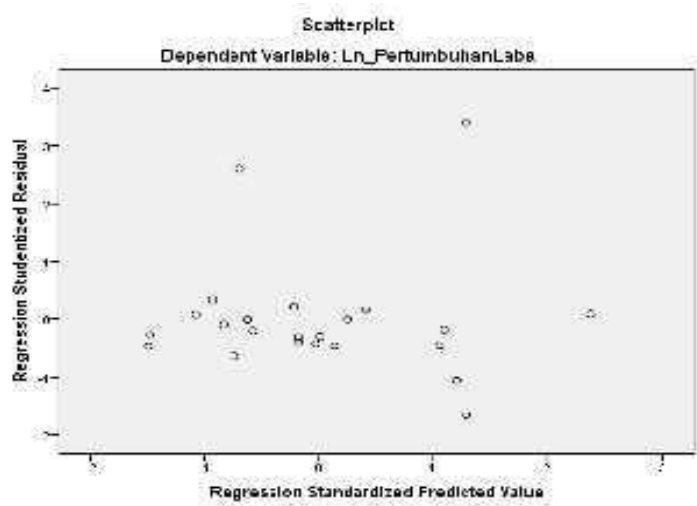

Sumber: Data Output SPSS

\section{Perusahaan Asuransi Konvensional}

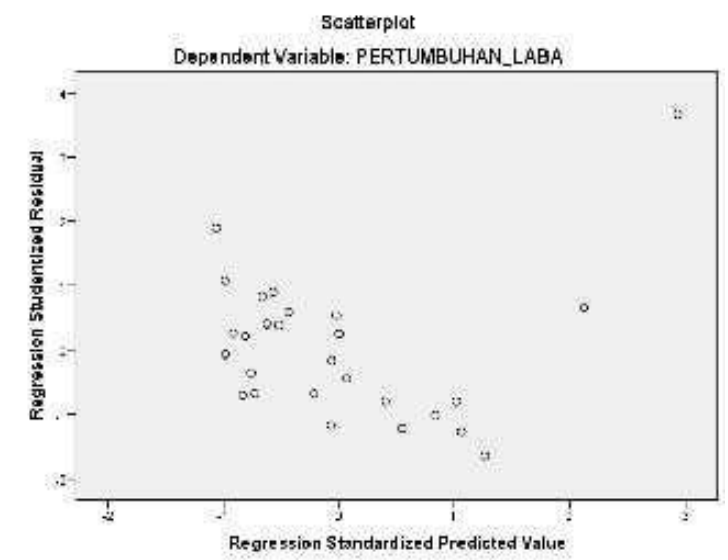

Sumber: Data Output SPSS

Uji Heteroskedastisitas menguji apakah dalam sebuah model regresi terjadi ketidaksamaan varians dari residual dari suatu pengamatan ke pengamatan lain tetap atau berbeda. Dari hasil tersebut terlihat bahwa penyebaran residual adalah tidak teratur. Hal ini dapat dilihat pada plot 
yang terpencar dan tidak membentuk pola yang teratur. Dengan hasil demikian maka

\section{Uji Autokorelasi}

\section{Perusahaan Asuransi Syariah}

Model Summary ${ }^{\text {b }}$ dapat disimpulkan bahwa tidak terjadi gejala heteroskedastisitas.

\begin{tabular}{|c|c|c|c|c|c|}
\hline Model & $\mathbf{R}$ & R Square & Adjusted R Square & $\begin{array}{c}\text { Std.Error of the } \\
\text { Estimate }\end{array}$ & Durbin - Watson \\
\hline 1 & $.354^{\mathrm{a}}$ & .125 & .110 & 68.64407 & 1.814 \\
\hline
\end{tabular}

a. Predictors: (Constant), INVESTASI, KLAIM, PREMI

b. Dependent Variable: PERTUMBUHAN_LABA

Sumber: Data output SPSS.

Uji Autokorelasi bertujuan menguji apakah dalam model regresi linear ada korelasi antara kesalahan pengganggu pada periode $t$ dengan kesalahan pengganggu pada periode $t-1$ (sebelumnya). Dalam penelitian ini autokorelasi dideteksi dengan menggunakan metode Durbin Watson
(DW).Kriteria tidak terjadinya autokorelasi adalah jika du $<$ nilai DW $<$ 4-du. Berdasarkan tabel Durbin Watson diperoleh nilai du adalah 1.651, maka $1.651<1.814<(4-1.651)$. Hal ini menunjukkan bahwa tidak terdapat autokorelasi.

\section{Perusahaan Asuransi Konvensional}

Model Summary ${ }^{b}$

\begin{tabular}{|c|c|c|c|c|}
\hline Model & R & R Square & Adjusted R Square & Std. Error of the Estimate \\
\hline 1 & $.996^{\mathrm{a}}$ & .992 & .991 & .00944 \\
\hline
\end{tabular}

a. Predictors: (Constant), INVESTASI, KLAIM, PREMI

b. Dependent Variable: PERTUMBUHAN_LABA

Sumber: Data Output SPSS

Berdasarkan hasail uji autokorelasi didapat angka sebesar 2,087 berarti berada diantara 1,54-2,4. Menurut tabel rentang nilai Durbin-Watson maka apabila berada diantara 1,54 - 2,4 tidak menolak Ho, berarti tidak ada autokorelasi. Dengan demikian penelitian ini terbebas dari masalah autokorelasi.

\section{Analisis Regresi Berganda}

\section{Perusahaan Asuransi Syariah}

\begin{tabular}{|c|c|c|c|c|c|}
\hline \multirow{2}{*}{ Model } & \multicolumn{2}{|c|}{ Unstandardized Coefficients } & Standardized & $t$ & Sig. \\
\hline & $B$ & Std. Error & Beta & & \\
\hline $\begin{array}{r}1 \text { (Constant) } \\
\text { PREMI }\end{array}$ & $\begin{array}{r}.790 \\
-.642\end{array}$ & $\begin{array}{r}2.455 \\
.350\end{array}$ & -.994 & $\begin{array}{r}.322 \\
-1.834\end{array}$ & $\begin{array}{l}.751 \\
.082\end{array}$ \\
\hline $\begin{array}{r}\text { KLAIM } \\
\text { INVESTASI }\end{array}$ & $\begin{array}{r}-.400 \\
.935\end{array}$ & $\begin{array}{l}.186 \\
.462\end{array}$ & $\begin{array}{r}-.686 \\
1.224\end{array}$ & $\begin{array}{r}-2.153 \\
2.022\end{array}$ & $\begin{array}{l}.044 \\
.058\end{array}$ \\
\hline
\end{tabular}


Hasil analisis regresi adalah berupa koefisisen untuk masing -masing variabel independen. Koefisien ini diperoleh dengan cara memprediksi nilai variabel dependen dengan suatu persamaan. Adapun persamaan regresi yang didapat dari tabel 4.14 di atas adalah :

$$
Y=790-642 X_{1}-400 X_{2}+935 X_{3}
$$

Dimana:

$$
\begin{aligned}
& \mathrm{Y}=\text { Pertumbuhan Laba } \\
& \mathrm{X} 1=\text { Premi } \\
& \mathrm{X} 2=\text { Klaim } \\
& \mathrm{X} 3=\text { Investasi }
\end{aligned}
$$

\begin{tabular}{|c|c|c|c|c|c|}
\hline \multirow[t]{2}{*}{ Model } & \multicolumn{2}{|c|}{ Unstandardized Coefficients } & Standardized & $\mathrm{t}$ & Sig. \\
\hline & $\mathrm{B}$ & Std. Error & Beta & & \\
\hline $\begin{array}{r}1 \text { (Constant) } \\
\text { PREMI }\end{array}$ & $\begin{array}{l}.162 \\
.001\end{array}$ & .050 & .014 & $\begin{array}{l}3.271 \\
.587\end{array}$ & $\begin{array}{l}.003 \\
.563\end{array}$ \\
\hline $\begin{array}{r}\text { KLAIM } \\
\text { INVESTASI }\end{array}$ & $\begin{array}{l}-.053 \\
.046\end{array}$ & $\begin{array}{l}.001 \\
.002\end{array}$ & $\begin{array}{l}-.757 \\
.596\end{array}$ & \begin{tabular}{|l|}
7.397 \\
25.338
\end{tabular} & $\begin{array}{l}.000 \\
.000\end{array}$ \\
\hline
\end{tabular}

\section{Perusahaan Asuransi Konvensional}

Coefficients $^{a}$

\section{Sumber : Data output SPSS}

Hasil analisis regresi adalah berupa koefisisen untuk masing -masing variabel independen. Koefisien ini diperoleh dengan cara memprediksi nilai variabel dependen dengan suatu persamaan.

$$
Y=162-001 X_{1}-053 X_{2}+046 X_{3}
$$

Adapun persamaan regresi yang didapat dari tabel 4.15 di atas adalah :

Dimana:

$$
\begin{aligned}
& Y=\text { Pertumbuhan Laba } \\
& X 1=\text { Premi } \\
& X 2=\text { Klaim } \\
& X 3=\text { Investasi }
\end{aligned}
$$

\section{Uji Signifikansi Simultan (Uji Statistik F)}

\section{Perusahaan Asuransi Syariah}

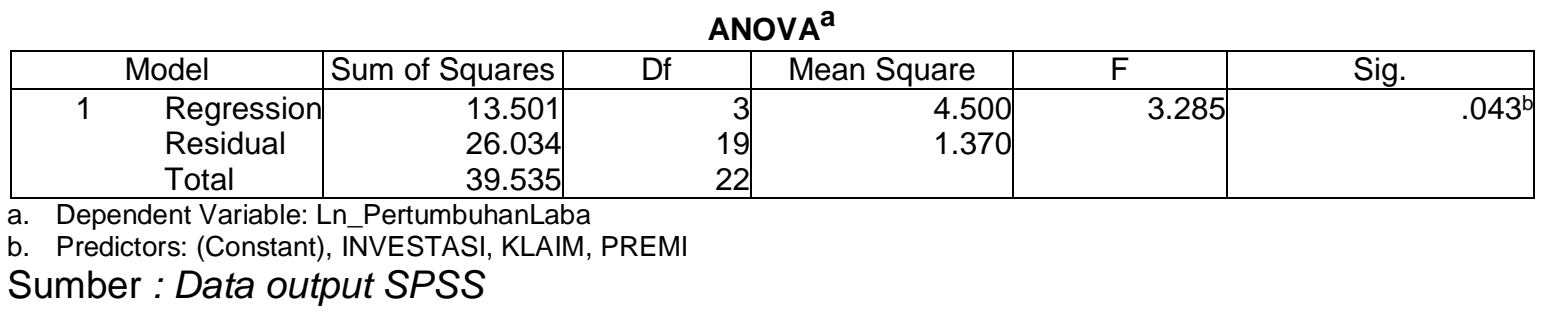

Dari tabel 4.18 hasil pengujian atas koefisien regresi berganda, diperoleh $F$ hitung sebesar 3.285 dengan tingkat signifikansi sebesar 0,043 . Untuk nilai $F$ tabel dapat dicari pada tabel $\mathrm{F}$ dengan N1 sebesar 3 dan N2 sebesar 23 maka dapat diperoleh nilai $\mathrm{F}$ tabel sebesar 2.85 pada nilai signifikansi sig. $0.043>0.050$. Artinya nilai $F$ hitung lebih besar dibandingkan dengan $\mathrm{F}$ tabel dan nilai signifikansinya lebih kecil dari alpha (5\%) yaitu 0.043 , maka kesimpulan yang dapat diperoleh dari hasil diatas adalah $\mathrm{Ho}$ ditolak dan $\mathrm{Ha}$ diterima artinyapremi, klaim, dan investasi secara bersama-sama (simultan) berpengaruh terhadap pertumbuhan laba. 


\section{Perusahaan Asuransi Konvensional}

\begin{tabular}{|c|c|c|c|c|c|c|}
\hline \multicolumn{7}{|c|}{ ANOVA $^{a}$} \\
\hline & Model & Sum of Squares & Df & Mean Square & $\mathrm{F}$ & Sig. \\
\hline 1 & $\begin{array}{l}\text { Regression } \\
\text { Residual } \\
\text { Total }\end{array}$ & $\begin{array}{r}.250 \\
.002 \\
253\end{array}$ & \begin{tabular}{r|}
3 \\
23 \\
26
\end{tabular} & $\begin{array}{l}.083 \\
.000\end{array}$ & 937.038 & $.000^{\mathrm{b}}$ \\
\hline
\end{tabular}

a. Dependent Variable: PERTUMBUHAN LABA

b. Predictors: (Constant), INVESTASI, KLAIM, PREMI

Sumber: Data Output SPSS

Dari tabel 4.19 hasil pengujian atas koefisien regresi berganda, diperoleh $F$ hitung sebesar 3.285 dengan tingkat signifikansi sebesar 0,000 . Untuk nilai $F$ tabel dapat dicari pada tabel $\mathrm{F}$ dengan $\mathrm{N} 1$ sebesar 3 dan N2 sebesar 23 maka dapat diperoleh nilai $\mathrm{F}$ tabel sebesar 937.038 pada nilai signifikansi sig. $0.000>0.050$.

\section{Koefisien Determinasi $\left(\mathbf{R}^{2}\right)$}

\section{Perusahaan Asuransi Syariah}

Model Summary ${ }^{\text {b }}$

\begin{tabular}{|c|c|c|c|c|}
\hline Model & $\mathrm{R}$ & $\mathrm{R}$ Square & Adjusted R Square & Std. Error of the Estimate \\
\hline 1 & $354^{\mathrm{a}}$ & .125 & .110 & 68.64407 \\
\hline
\end{tabular}

a. Predictors: (Constant), INVESTASI, KLAIM, PREMI

b. Dependent Variable: PERTUMBUHAN_LABA

Sumber: Data Output SPSS

Besarnya koefisien determinasi pada tabel 4.20 adalah sebesar 0.11 atau $11 \%$. Artinya perubahan dalam Pertumbuhan Laba dapat dijelaskan sebesar $11 \%$ oleh perubahan atau Premi,

Artinya nilai $F$ hitung lebih besar dibandingkan dengan $F$ tabel dan nilai signifikansinya lebih kecil dari alpha (5\%) yaitu 0.000 , maka kesimpulan yang dapat diperoleh dari hasil diatas adalah $\mathrm{Ho}$ ditolak dan $\mathrm{Ha}$ diterima artinyapremi, klaim, dan investasi secara bersama-sama (simultan) berpengaruh terhadap pertumbuhan laba.

\section{Perusahaan Asuransi Konvensional}

Model Summary ${ }^{\text {b }}$

\begin{tabular}{l|r|r|r|r|}
\hline Model & $\mathrm{R}$ & R Square & Adjusted R Square & Std. Error of the Estimate \\
\hline \multicolumn{1}{|c|}{$.996^{\mathrm{a}}$} & .992 & .992 & .00944 \\
\hline
\end{tabular}


Besarnya koefisien determinasi pada tabel 4.21 adalah sebesar 0.991 atau $91 \%$. Artinya perubahan dalam Pertumbuhan Laba dapat dijelaskan sebesar $91 \%$ oleh perubahan atau Premi, Klaim, dan Investasi. Sedangkan sisanya sebesar 9\% dijelaskan oleh variabel lain yang tidak diperhitungkan dalam penelitian ini.

\section{Pembahasan pengaruh Premi, klaim, dan investasi Terhadap Pertumbuhan Laba Pada Perusahaan Asuransi Syariah}

Premi adalah sejumlah uang yang harus dibayarkan setiap bulannya sebagai kewajiban dari tertanggung atas keikutsertaannya di asuransi. Besarnya premi atas keikutsertaan di asuransi yang harus di bayarkan telah di tetapkan oleh perusahaan asuransi dengan memperhatikan keadaan-keadaan dari tertanggung. Sedangkan klaim merupakan pengajuan hak yang di lakukan oleh tertanggung kepada penanggung untuk mendapatkan haknya berupa pertanggungan atas kerugian berdasarkan perjanjian atau akad yang telah dibuat. (Abdul Amin, 2006).

Berdasarkan hasil uji $\mathrm{t}$ diketahui bahwa besarnya nilai thitung untuk variabel premi $=$ - 1.834 lebih kecil dari ttabel sebesar 2.021 dengan tingkat signifikan $0.82>0.05$. Dengan adanya hasil yang seperti ini maka hipotesis pertama $(\mathrm{H} 1)$ ditolak karena premi tidak berpengaruh terhadap pertumbuhan laba. Hasil ini sejalan dengan penelitian yang dilakukan oleh M.Agung Ali Fikri (2009) yang menunjukkan bahwa premi tidak berpengaruh terhadap laba.

Klaim adalah pengajuan hak yang dilakukan oleh tertanggung kepada penanggung untuk mendapatkan haknya berupa pertanggungan atas kerugian berdasarkan perjanjian atau akad yang telah di buat. Dengan kata lain, klaim adalah proses pengajuan oleh peserta untuk mendapatkan uang pertanggungan setelah tertanggung melaksanakan seluruh kewajibannya kepada penanggung, yaitu berupa penyelesaian pembayaran premi sesuai dengan kesepakatan sebelumnya. (Abdul Amin, 2006).
Dari hasil uji $t$ diketahui bahwa besarnya nilai thitung untuk variabel klaim $=2.153$ lebih besar dari ttabel sebesar 2.021 dengan tingkat signifikansi 0,044 dengan tingkat signifikasi $0.044<0.05$ maka Ho ditolak $\mathrm{H} 2$ diterima.

Menurut Lawrence \& Michael (Sula, 2004:379), investasi dalam perusahaan asuransi dapat diartikan sebagai suatu portofolio yang artinya adalah kumpulan bentuk investasi yang terpadu untuk tujuan mendapatkan keuntungan investasi. Tujuan utama dari pembentukan suatu portofolio adalah tidak lain untuk mendapatkan hasil yang optimal dengan resiko yang minimal. Hasil investasi tersebut diperoleh dari penanaman modal dengan melakukan diversifikasi portofolio untuk mendapatkan perolehan bagi hasil yang optimum. Hasil investasi memegang peranan penting bagi pendapatan perusahaan asuransi syariah

Dari hasil uji $t$ diketahui bahwa besarnya nilai thitung untuk variabel investasi $=2.022$ lebih besar dari nilai ttabel sebesar 2.021 dengan tingkat signifikansi $0.058>0.05$ maka H3 ditolak dan $\mathrm{Ho}$ diterima, artinya tidak ada pengaruh yang signifikan antara investasi terhadap pertumbuhan laba

Berdasarkan hasil uji-F yang telah dijelaskan sebelumnya, kesimpulan yang dapat diperoleh dari perusahaan asuransi syariah adalah premi, klaim, dan hasil investasi secara bersama-sama (simultan) berpengaruh terhadap pertumbuhan lab. Hal ini dikarenakan $F$ hitung yang diperoleh sebesar 3.285 lebih besar dari F tabel 2.85 dengan tingkat signifikansi sebesar $0,043<$ 0,05 .

\section{Pengaruh premi, Klaim, dan investasi Terhadap Pertumbuhan Laba Pada Perusahaan Asuransi Konvensional}

Premi adalah salah satu unsur
penting dalam asuransi karena
merupakan kewajiban utama yang wajib
dipenuhi oleh tertanggung kepada
penanggung (Pasal 246 KUHD).
Hasil uji t perusahaan asuransi
konvensional diketahui bahwa besarnya
nilai thitung untuk variabel premi= -0.587
lebih kecil dari ttabel sebesar 2.021
dengan tingkat signifikan $563>0.05$.


Dengan adanya hasil yang seperti ini maka hipotesis pertama (H1) ditolak karena premi tidak berpengaruh terhadap pertumbuhan laba.

Menurut PSAK No. 28 klaim adalah ganti rugi yang dibayarkan atau yang menjadi kewajiban kepada tertanggung atau perusahaan asuransi (ceding company) sehubungan dengan telah terjadinya kerugian.

Dari hasil uji t perusahaan asuransi konvensional diketahui bahwa besarnya nilai thitung untuk variabel klaim $=7$.lebih besar dari ttabel sebesar 2.021 dengan tingkat signifikasi $0.000<0.05$ maka Ho ditolak dan $\mathrm{H} 2$ diterima, artinya klaim berpengaruh positif signifikan terhadap pertumbuhan laba.

Investasi adalah menempatkan uang atau dana dengan harapan untuk memperoleh tambahan atau keuntungan tertentu atas uang atau dana tersebut. Pengertian investasi ini menekankan pada penempatan uang atau dana. Tujuan investasi ini adalah untuk memperoleh keuntungan. (Kamaruddin Ahmad).

Dari hasil uji t perusahaan asuransi konvensional diketahui bahwa besarnya nilai thitung untuk variabel investasi $=$ 25.338 lebih besar dari nilai ttabel sebesar 2.021 dengan tingkat signifikansi 0.000 > 0.05 maka Ho ditolak dan H3 diterima, artinya hasil investasi berpengaruh positif signifikan terhadap pertumbuhan laba. Terdapat perbedaan antara hasil investasi terhadap pertumbuhan laba pada perusahan asuransi syariah dengan asuransi konvensional.

Berdasarkan hasil uji-F perusahaan asuransi konvensional adalah premi, klaim, dan hasil investasi secara bersama -sama (simultan) berpengaruh terhadap pertumbuhan lab. Hal ini dikarenakan $F$ hitung yang diperoleh sebesar 937.038 lebih besar dari $F$ tabel 2.85 dengan tingkat signifikansi sebesar 0,000<0,05.

Perbedaan Pengaruh Premi, Klaim, dan Hasil Investasi terhadap Pertumbuhan Laba Pada Perusahaan Asuransi Syariah Dengan Asuransi Konvensional

Tabel dibawah ini akan menjelaskan bagaimana pengaruh premi, klaim, dan investasi terhadap pertumbuhan lab pada perusahaan asuransi syariah dengan asuransi konvensional adalah sebagai berikut.

Perbedaan Pengaruh Premi, Klaim, dan Hasil Investasi terhadap Pertumbuhan Laba Pada Perusahaan Asuransi Syariah Dengan Asuransi Konvensional

\begin{tabular}{|l|c|c|c|c|}
\hline \multicolumn{1}{|c|}{ Analisis } & Asuransi & Premi & Klaim & Investasi \\
\hline R2 & Syariah & $8,2 \%$ & $4.4 \%$ & $5.8 \%$ \\
\hline \multirow{2}{*}{ Sig t } & Konvensional & $5.8 \%$ & $0 \%$ & $0 \%$ \\
\hline & Syariah & 0.043 & 0.043 & 0.043 \\
\hline
\end{tabular}

Tingkat Signifikan $5 \%$

Sumber: Data Output SPSS

Berdasarkan hasil dari tabel diatas dapat diketahui bahwa pendapatan premi dan hasil investasi tidak berpengaruh terhadap pertumbuhan laba pada perusahaan asuransi syariah hal ini cukup beralasan karna setiap premi yang dibayarkan oleh nasabah kepada asuransi mengandung unsur resiko yang memicu terjadinya klaim. Sedangkan klaim berpengaruh terhadap pertumbuhan laba pada asuransi syariah. Namun secara bersama-sama (simultan) premi, klaim, dan investasi berpengaruh terhadap pertumbuhan laba pada perusahaan asuransi syariah.

Sedangkan untuk perusahaan asuransi konvensional premi tidak berpengaruh terhadap pertumbuhan laba, tetapi klaim dan investasi berpengaruh signifikan terhadap pertumbuhan laba. Namun secara bersama-sama (simultan) premi, klaim, dan investasi berpengaruh terhadap pertumbuhan laba pada perusahaan asuransi konvensional. 


\section{KESIMPULAN}

Penelitian ini bertujuan untuk mengetahui bagaimana perbedaan pengaruh premi, klaim, dan investasi terhadap pertumbuhan laba pada asuransi syariah dengan asuransi konvensional.

Pada perusahaan asuransi syariah, Premi dan hasil investasi tidak berpengaruh terhadap pertumbuhan laba. Hal ini cukup beralasan karena setiap premi yang dibayarkan oleh nasabah kepada asuransi mengandung unsur resiko yang memicu terjadinya klaim. Sedangkan klaim berpengaruh terhadap pertumbuhan laba. Hal ini menunjukan bahwa dimana semakin besar utang klaim maka semakin kecil laba yang dapat diperoleh perusahaan.Namun secara bersama-sama (simultan) premi, klaim, dan investasi berpengaruh tehadap pertumbuhan laba. Adapun besar variasi dalam pertumbuhan laba sebesar $11 \%$ dapat di jelaskan oleh faktor premi, klaim, dan hasil investasi. Sedangkan sisanya sebesar $89 \%$ dijelaskan oleh variabel lain yang tidak diperhitungkan dalam penelitian ini.

Pada perusahaan asuransi konvensional, Premi tidak berpengaruh terhadap pertumbuhan laba. Sedangkan Klaim dan hasil investasi berpengaruh terhadap pertumbuhan laba. Halini menunjukan bahwa semakin besar premi yang diterima perusahaan asuransi, maka semakin besar pula dana yang diinvestasikan sehingga diperoleh hasil investasi yang semakin besar, dimana semakin besar hasil investasi maka semakin besar pula laba yang di peroleh perusahaan, begitu juga sebaliknya.Namun secara bersama-sama (simultan) Premi, Klaim, dan Investasi berpengaruh terhadap pertumbuhan laba adapun besar variasi dalam prtumbuhan laba sebesar $91 \%$ dapat dijelaskan oleh faktor premi, klaim, dan hasil investasi. Sedangkan sisanya 9\% dijelaskan oleh variabel lain yang tidak diperhitungkan dalam penelitian ini.

Perbedaan pengaruh premi, klaim, dan investasi pada perusahaan asuransi syariah dengan asuransi konvensional bahwa pendapatan premi dan hasil investasi tidak berpengaruh terhadap pertumbuhan laba pada perusahaan asuransi syariah hal ini cukup beralasan karna setiap premi yang dibayarkan oleh nasabah kepada asuransi mengandung unsur resiko yang memicu terjadinya klaim. sedangkan klaim berpengaruh terhadap pertumbuhan laba pada asuransi syariah. Namun secara bersama-sama (simultan) premi, klaim, dan investasi berpengaruh terhadap pertumbuhan laba pada perusahaan asuransi syariah.Sedangkan untuk perusahaan asuransi konvensional premi tidak berpengaruh terhadap pertumbuhan laba, tetapi klaim dan investasi berpengaruh signifikan terhadap pertumbuhan laba. Namun secara bersama-sama (simultan) premi, klaim, dan investasi berpengaruh terhadap pertumbuhan laba pada perusahaan asuransi konvensional.

\section{IMPLIKASI KETERBATASAN}

DAN

Berdasarkan kesimpulan diatas, maka dapat diajukan beberapa saran dari hasil penelitian yang diperoleh yaitu:

agar $\begin{array}{rr}\text { Perusahaan asuransi } & \text { diharapkan } \\ \text { mengoptimalkan } & \text { kegiatan }\end{array}$ operasionalnya dan kegiatan pemasaran produknya serta lebih sering melakukan kegiatan sosialisasi mengenai pentingnya berasuransi agar dapat menarik minat dan kepercayaan masyarakat untuk melakukan asuransi. Semakin banyak masyarakat berasuransi maka semakin besar peluang untuk menghasilkan keuntungan yang maksimal bagi perusahaan.

Penelitian selanjutnya dapat menambah variabel lain yang diduga dapat mempengaruhi pertumbuhan laba. Juga menambah sempel yang lebih banyak, dan periode lebih panjang agar didapat hasil penelitian yang lebih akurat.

\section{DAFTAR PUSTAKA}

Dahlquist R. M., T. S. Prather and J. J. Stapleton, 2010. Time and Temperature Requirements for Weed Seed Thermal Death. Weed Science, 55: 619-625.

Darsono dan Ashari, 2005, Pedoman Praktis Memahami laporan Keuangan, Andi, Yogyakarta 
Bodie et all, 2006. Investasi, Alih Bahasa oleh Zuliani Dalimunthe dan Budi Wibowo, Salemba Empat, Jakarta.

Copeland, Thomas E., J Fred Weston, (2010), Financial Theory And Corporate Policy, $5^{\text {th }}$ Ed, AddisonWesley Publishing Company, Inc, USA.

Elton dan Gruber. 2011. Modern Portofolio : Theory and Investment Analysis, $5^{\text {th }}$ edition. New York : Wiley.

Ferdinand. 2006. Metode Penelitian Manajemen . Semarang: Badan Penerbit Universitas Diponegoro.

Hamid, Abdul. "Pasar Modal Syariah". Lembaga Penelitian UIN Jakarta, Jakarta, 2009.

Hamid, Ibid," Lembaga Kauangan Syariah", Jakarta: Penerbit Zikrul Hakim,2008.

Huda Nurul, Investasi Pada Pasar Modal Syariah. Prenada Media Grop: Jakarta, 2007.

Ghozali, Imam. 2006. "Aplikasi Analisis Multivariate Dengan Program SPSS ".Semarang : Badan Penerbit Undip.

Ghozali, Imam. 2013. Aplikasi Analisis Multivariate dengan Program SPSS . Edisi Ketujuh. Semarang: Badan Penerbit Universitas Diponegoro

Jones, Charles P., 2007, Investment, New York : Prentice-Hall.

Kon, Teori Portofolio Dan Analisis Sekuritas, Unit Penerbit Dan Percetakan AMP YKPN Yogyakarta, 2007.
Markowitz, N. Gregory. "Principle of Economics Pengantar Ekonomi Makro". Edisi Tiga, Salemba Empat, Jakarta, 2008.

Nofie Iman. 2008. Panduan Singkat dan Praktis: Memulai Investasi Reksadana, PT Elex Media Komputindo, Jakarta

Pratomo, Eko Priyo dan Ubaidillah Nugraha. "Reksa Dana Solusi Perencanaan Investasi di Era Modern". PT Gramedia Pustaka Utama, Jakarta, 2009.

Pratomo, Eko P. "Berwisata ke Dunia Reksa Dana". PT Gramedia Pustaka Utama, Jakarta, 2008.

Sharpe, William F, et.al.(2008), Investment, $5^{\text {th }}$ edition, Prentice Hall, New Jersey.

Sudarsono, Heri. "Bank dan Lembaga Keuangan Syariah Edisi 3”. Ekonisia, Yogyakarta, 2008.

Sugiyono. (2008). MetodePenelitian Kuantitatif Kualitatif \& RND. Bandung : Alfabeta

Wiksuana I.G.B., Purnawati N.K., 2008, Konsistensi Risk-Adjusted Performance Sebagai Pengukur Kinerja Portofolio Saham Di Pasar Modal Indonesia, Buletin Studi Ekonomi No 13 Volume 2 Tahun 2008, Universitas Udayana.

\section{WEBSITE}

http://sagalawira92.blogspot.com/2013/05/ perbedaan-asuransi-syariah-dengan.html,

Http://Ronylendeo.Blogspot.Com/2011/10/ Asuransi.Htm Http://Www.Kembar.Pro/2014/ 
(2019) Islamic Economic, Accounting and Management Journal (Tsarwatica) 

